（30）徰生動物 1961 年 Vol. 12 No. 1

talpoides and in comparison with the Hiroshima-type the scope of the host appears to be narrow. Also, the Kii-type was collected from forest but not from field and residential section. As compared with the Kii-type obtained in Kii, no difference was obtained generally in sizes of scutum. Some consideration has been made on the distribution of the Kii-type in Miyazaki Prefecture, but a satisfactory explanation on the geographical distribution, variation and so on will depend a great deal upon the future studies.

\title{
杤木県の竹林における蚊の生態学的研究
}

\author{
第 3 報 宇都宮市の竹林マダケ切株における蚊幼虫
}

\section{Ecological studies on mosquitoes in the bamboo groves of Tochigi Prefecture III. Mosquito larvae in the stumps of bamboo (Madake) in Utsunomiya City}

\author{
倉茂好雄* \\ Yoshio Kurashige
}

\begin{abstract}
緒言
当地方の農家, 寺院等には冬季の寒風を防ぐため, 宅地 境内等の一部に小規模の竹林が存在し, 蚊発生のよき環 境を形成している.著者はこのような竹林の1つとして 県南, 小山市の農村地帯の 1 竹林モウソウチク切株にお (ける蚊幼虫を調查しその結果を第 1 報了! に，またその成 績と従来報告された関西および東北地方の竹林における 成績との比較考察を第 2 報“蕔告した今回は第 3 報と 乙て, 小山市の北方的 $30 \mathrm{~km}$, ほぼ県の中央に位置する宇 都宮市郊外の 1 竹林内マダケ切株における蚊幼虫につい て調査し，小山のモウソウチク切株における成績と著し く異なる成績を得たので，その結果をここに報告する.
\end{abstract}

\section{調查竹林}

調查の対象とした竹林は都心からやや離れた宇都宮市 㮦町宇都宮大学構内の農場西端にある約 20 アールの小 竹林であつて，東および南側には畑地があり，西側には 道路を距てて低くなつた水田が広く展開しており, 北側 には大学の建物が点在する. 竹林のすぐ北側には 2 棟の 公舎があるだけで附近に入家は存在しない.したがつて この竹林は, 普通の農家におけるような防風林としての 意味はなく, 専ら農場における支柱等の供給源として用 いられている.この竹林を構成するものはほとんどマダ

* 宇都宮大学学芸学部生物学教室

Biological Laboratory, Faculty of Liberal Arts Utsunomiya University
ケであつて，これにわずかのモウソウチクが 1 部に存在 していた。 なお竹林内には灌木や雑草がよく茂つてい た.これらの竹は普通のこぎりを以て切断されるのでそ の切株には微陸水域の認められるものが多かつた。

\section{铜查の方法}

上記竹林内にあるマダケ切株のうち, 調查開始当時微 陸水域の存在した切株 30 個につき調查した. 調查は, 1957 年 5 月 16 日から 11 月 8 日までの 6 力月間, 24 回, 延 720 水域につき行なつた. このうち，5月 16 日から 6 月 13 日までの 4 回は無選択的に水域の存在した 30 個 の切株について調查したが, 第 5 回の 6 月 20 日以降の 調查では小山における調查と同様に 30 個の切株に通し 番号を明記し，これらの切株について継続的に調查を行 ない，各切株における蚊出現の様相をも追求した。蚊の 採集は小山におけると同様に容量 $5 \mathrm{cc}$ のスポイトを用 いて 5 回吸取り, 若龄 $(1,2$ 龄)および高龄 $(3,4$ 齢) 幼 虫, 蛹の別にす心゙ての個体数を記録した. 若㱓幼虫は竹 切株別に試験管内で飼育して終龄幼虫または成虫で同定 し，蛹は羽化させてから成虫で同定した，なお成虫の同 定には専ら双眼実体顕微鏡を使用し, さらに必要に応じ て成体雌雄の外部生殖器を検鏡した。

\section{諷查成綨と考察}

調查した竹切株は内径 $1.4 \sim 4.7 \mathrm{~cm}$ であり, ほとんど 切断後 1 年以上の古いものであつて切口の維管束が黒ず んでいた.これら切株内の微陸水域には淡黄色ないし淡 
褐色の水があり, 多くの切株には竹葉が堆積し, また水 底には腐植泥が沈積していた。

\section{1. 出琾した蚊}

採集された蚊幼虫の種類および個体数は表 1 のとおり である.表示のように 1 属 2 種， 537 個体が採集され， そのうち Ae. flavopictus ヤマダシマカが $85.3 \%$ 压 倒的に多く, Ae. albopictus ヒトスジマカは $14.7 \%$ で あつて前者よりはるかに少なかつた。 またこれら両種 の蚊が切株に出現した頻度は表 2 のようであり，Ae. flavopictus 153 回(77.3\%), Ae, albopictus 45 回(22.7 \%) であつて前者の出現頻度は後者のそれに比し極めて

Table 1 Species and number in individuals of the mosquito larvae collected in the bamboo stumps from June to November, 1957 in Utsunomiya City

\begin{tabular}{c|r|r|r|r|r|r}
\hline \hline \multirow{2}{*}{ Species } & \multicolumn{2}{|c|}{ Larvae } & Pupae & Total & $\%$ \\
\cline { 2 - 6 } & $\begin{array}{c}\text { I, II } \\
\text { instar }\end{array}$ & $\begin{array}{l}\text { III, IV } \\
\text { instar }\end{array}$ & & & \\
\hline Aedes flavopictus & 199 & 190 & 69 & 458 & 85.3 \\
Aedes albopictus & 36 & 33 & 10 & 79 & 14.7 \\
\hline Total & 235 & 223 & 79 & 537 &
\end{tabular}

Table 2 Frequency of appearance of the mosquito larvae found in bamboo stumps

\begin{tabular}{c|r|c}
\hline Species & Observed & $\%$ \\
\hline Ae. flavopictus & 153 & 77.3 \\
Ae. albopictus & 45 & 22.7
\end{tabular}

高かつた.このようにAe. flavopictus は Ae. albopictus に比し，出現した幼虫数においても，また出現頻度にお いても著しく優つており, 採集 1 回当りの平均幼薮は 前者が 2.9 個体，後者が 1.8 個体であつて，切株内にお ける幼虫の棲息密度も前者の方がはるかに大であつた.

本邦の竹林に㧍ける従来の蚊幼虫調查成績から出現し た蚊の種類をあげてみると，加藤ら (1951) ${ }^{1}$ は宮城県の 竹林における夏秋季の調查により Tripteroides bambusa, Ae. flavopictus, Ae. japonicus, Ae. niponicus, Armigeres subalbatus および Culex tritaeniorhynchus の 4 属 6 種を，中田ら $(1953)^{51}$ は京都の竹林における周 年調查により Uranotaenia bimaculata, Ae. flavopictus, Tr. bambusa, Ar. subalbatus, Ae. japonicus および Ae. albopictus の 4 属 6 種を，また柇原 $(1956)^{6 !}$ は三重県の竹林における冬季の調查により Tr. bambusa, Ur. bimaculata, Ar. subalbatus, Ae. flavopictus および Ae. albopictus の 4 属 5 種を報告した. 今回の 成績は上記の諸成績に比し出現した蚊の種類が著しく少
ない.しかし上記した従来の報告における竹切株の竹種 については，加藤らのはモウンウチクを対象としたよう に推定され(加藤 $1955^{21}$ )，上記中田らは専らモウンウチ クを，また榊原は八チク，モウンウチク，マダケの 3 種

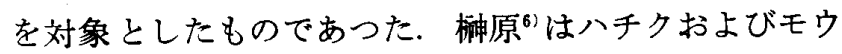
ソウチク切株にはそれぞれ蚊の発生を認めたが，マダケ 切株にはいずれの種類の蚊も発見できなかつた。しかも この報告によると，八チク切株には Ae. albopictus を も発生し，またモウソウチク切株には Ae. flavopictus をも発生していたこれらの報告からも，蚊の発生につ いてーダケ切株がモウソウチク切株と異なることが察知 されるが，小山のモウソウチク切株における成績と今回 のマダケ切株におけるそれとを比較検討して少しく考察 したい.

著者 $(1960 \text { a })^{3 /}$ が同年 7 月 28 日から 9 月 29 日まで杤 木県小山市の竹林においてモウソウチク切株 30 個延心゙ 210 水域について行なつた蚊幼虫の調查成績では, 同様 な採集方法を以て, Tr. bambusa $(40.1 \%), A e$. flavopictus $(29.5 \%)$, Ae. albopictus (18.6\%), Ar. subalbatus $(10.0 \%)$, Ur. bimaculata $(1.2 \%)$ および Ae. japonicus (0.6\%)の4属 6 種の蚊が採集されたの であつた，小山におけるこの成績に比し，今回の調查は 採集期間も長く, 採集した延水域数も多く,小山の約 3 倍 であつたにもかかわらず，蚊の種類に乏しく，かつ個体 数漂度に少なく, 小山の約 $1 / 3$ に過ぎなかつた. Ae. favopictus 㧍よび Ae. albopictus が小山と宇都宮の両 地に共通した蚊であり，また前者が後者より多数出現し た蚊であることは両地同様であるが，小山のモウソウチ ク切株に出現した Tr. bambusa やUr. bimaculata等 が今回の調査では全く発見できなかつた.このように同 一年, 同一県内で, しかも約 $30 \mathrm{~km}$ の近距離にある小山の モウソウチク切株における蚊幼虫の発生と宇都宮のマダ ケ切株における蚊幼虫の発生には上述のように極わめて 顕著な差異が認められたのであるが，これは小山と宇都 宮といら生物地理的な地域の差異によるよりも（温度は 後述のように小山の方が高いが), モウソウチクとマダ ケという竹種の差異に基ゔくものでモウンウチク切株と マダケ切株との形成する蚊の発生環境の差違によるもの と推定される.

\section{2. 蚊幼虫の季節的消長}

5 月中旬から 11 月上旬までの約 6 力月間に, 竹切株に 出涀した蚊幼虫の個体数およびその出現頻度がどのよう な季節的消長をたどつたかを各採集回ごとにまとめて考 察した。まゔ全体の蚊は 5 月中旬には既にかなり多く出 現し，下旬にやや増加して小さい山を描くが，6月に入 ると次第に減少し下旬に最も少なくなり，7月に入り中 


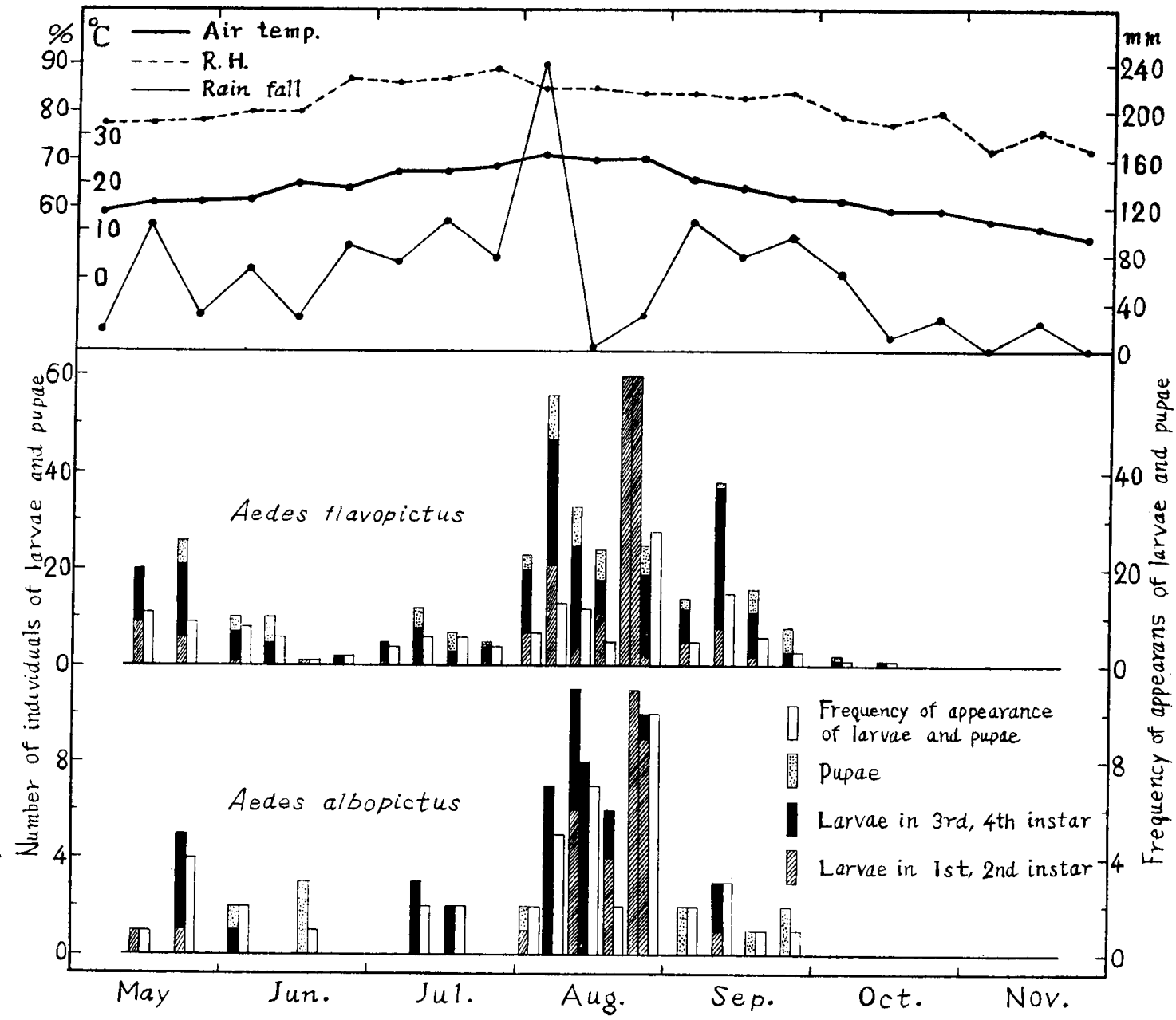

Fig. 1 Seasonal prevalence of number of individuals and frequency of appearance of the mosquito larvae in bamboo stumps in Utsunomiya City

们一時やや増加するが下旬には再び減少した８月に人 ると急に増加し下旬の 8 月 30 日に最高の個体数を示し, 9 月上旬急に減少した.この成績は小山のモウソウチク 切株における蚊幼虫数が 8 月 29 日に最高を示したの上 ほとんど一致した。蚊は 9 月 12 日に一時増加し，後次 第に減少して 10 月 18 日以降全く出現しなかつた．竹切 株における蚊の出現頻度もほぼ上述した個体数の消長に 伴って変化し，5月中，下旬，6月上旬にやや高く，後次第 に低下して 6 月 20 日から下旬にかけて最低を示した。 その後次第に高くなり 7 月下旬一時低くなるが，後再び 上昇し 8 月 30 日に最高の出現頻度を示し 9 月中旬以降 次第に低下した。

次に蚊種別に幼虫の個体数および出現頻度の季節的消 長る示すと図 1 のとおりである. 気温，湿度および降水 量怯調查地点から西方 $4 \mathrm{~km}$ に位置する宇都宮測候所の 観測資料に基づき，旬間平均温度，旬間平均湿度および 旬間降水量を以て表わした. Ae. Alavopictus は 5 月中, 下旬に汸かなり多く出現して小さい山を描くが，6月に 入ると少なくなりまづ上旬にやや減少し，次いで中旬の
20 日から下旬には極度に減少して谷を示した. その後 7 月には少し増すが大きな増加はなく，8月に入ると急激 に増加して最大の山を現わし, 特に 8 月 30 日には極め て多数採集された. 本種の出現頻度の消長はほぼ個体数 の消長に伴つて変化しているが，8月の最盛期には出現 頻度に比し個体数の増加の割合がはなはだ大きくなり， 蚊が急速に繁殖してその棲息密度が大きくなつたことを 示した.Ae. albopictus の消長はほぼ前種と同様な消長 を示した.すなわち本種も 5 月に小山を描きその後 6 月 および 7 月には少なく, 特に 6 月下旬から 7 月上旬にか けて全く出現しなかつた，前種と同様に 8 月は本種発生 の最盛期であり，特に，中，下旬には最も多かつた，本 種の最後の出現日が 9 月 26 日であつたのに対し, 前種 のそれは 10 月 11 日であつて, 本種は前種より約 2 週間 早く姿を消した. 本種の出現頻度もまた個体数の消長に ほぼ伴つて変化するが，前種と同様に 8 月の最盛期には 出現頻度に比し個体数の増加の割合がすこぶる大であつ て, 蚊の棲息密度が大きく, しかむ若龄幼虫が多く，蚊 の繁殖が急速に行なわれたことを示した。 
竹林の切株に発生する蚊の消長に関する報告はただ京 都における中田ら $(1953)^{5}$ のものがあるのみである。こ れによる上，Ae. flavopictus は 4 月上旬から 8 月上旬 まではおおむね優位を占めるが 6 月中旬には一度急激 に減少した. Ae. Alavopictus の減少の谷が 6 月に生し ていることは京都の成績と今回のそれとはほぼ一致して いる。 また中田らによれば Ae. albopictus は8 月中, 下旬に多く採れており，今回の成績でも 8 月下妸に最も 多かつたのであつて両者の成績はよく類似している. 更 に今回の成績では蚊の最終出現日が Ae. flavopictus で は 10 月中旬, Ae. albopictus では 9 月下旬であつたこ とも中田らの京都における成績と全く一致していた.

次に若齢幼虫，高龄幼虫拉よび蛹の齢別構成とその変 遷を図 1 によつてみると，蚊の最も多数出現した 8 月下 旬には若龄幼虫が著しく多く, 高齢幼虫および蛹が極度 に少ないのであつて，前に述べたように蚊が急速に増殖 したことが察知される。これに反して蚊の最も減少した 6 月および 7 月には蛹または高龄幼虫が多く若龄幼虫が 極めて少なかつた。この現象は Ae. albopictus の場合 特に顕者であつて，6 月中旬と 9 月中，下旬には本種の 幼虫は全くみられず蛹のみ出現した。

著者 $(1960 \text { a })^{32}$ が本報々同年に調査した小山のモウソ ウチク切株における蚊幼虫の消長においては，Ae. flavopictus の最高の山が 8 月 4 日に出現したのであつて, 今 回の宇都宮に㧍ける 8 月 30 日より 26 日も早いし，また Ae. albopictus の最高の山は小山では 8 月 18 日であつ て宇都宮に扔引る 8 月 30 日上り 12 日早い. 両地におけ る同年夏季の温度を比較すると, 月平均温度は小山で は 7 月 $23.8^{\circ} \mathrm{C}, 8$ 月 $26.3^{\circ} \mathrm{C}$ であり，宇都宮では 7 月 $22.8^{\circ} \mathrm{C}, 8$ 月 $25.5^{\circ} \mathrm{C}$ であつて小山の方が宇都宮より, 7 月 $1^{\circ} \mathrm{C}, 8$ 月 $0.8^{\circ} \mathrm{C}$ 高く, また同年最高の旬間平均温 度は小山では 8 月上旬の $26.8^{\circ} \mathrm{C}$ であり，宇都宮では同 じく 8 月上旬の $25.8^{\circ} \mathrm{C}$ であつて, 年最高の旬間平均温 度においても小山の方が宇都宮より平均 $1.0^{\circ} \mathrm{C}$ 高かつ た.したがつて，宇都宮における蚊発生の最高の山の 出現期が小山におけるそれに比し多少おそいことが考穴 られる.小山で注この最高の旬間平均温度を示した 8 月 上旬に Ae. flavopictus が最も多数採れたのであるが, 宇都宮では更にこの旬間に $240.8 \mathrm{~mm}$ という異常な埕間 降水量があり(小山では僅か $15.9 \mathrm{~mm}$ )，そのため蚊の発 生が妨げられ旬間平均温度 $25.5^{\circ} \mathrm{C}$ を示した 8 月下旬に 最高の山が出現したものと推定される.

\section{3. 蚊幼虫群基の構成と毞移}

今回のマダケ切株においては, 僅かに 2 種の蚊が出現 し，表 3 に示すようにこれら両種の蚊がそれぞれ単独ま たは混合群集を形成したものであるが，群集は僅か 3 種
Table 3 Frequency of appearance and number of individuals of la val associations of mosquitoes

\begin{tabular}{l|r|r|r|r}
\hline \hline Larval association & \multicolumn{2}{|c|}{$\begin{array}{c}\text { requency of } \\
\text { appearance }\end{array}$} & \multicolumn{2}{c}{$\begin{array}{c}\text { Number of } \\
\text { larvae }\end{array}$} \\
\hline $\begin{array}{r}\text { obser- } \\
\text { ved }\end{array}$ & $\%$ & $\begin{array}{c}\text { obser- } \\
\text { ved }\end{array}$ & $\%$ \\
\hline Ae. flavopictus association & 126 & 73.7 & 377 & 70.2 \\
$\begin{array}{c}\text { Ae. albopictus } \text { association } \\
\text { Ae. flavopictus-Ae. }\end{array}$ & 18 & 10.5 & 31 & 5.8 \\
albopictus association & 27 & 15.8 & 129 & 24.0 \\
\hline Total & 171 & & 537 &
\end{tabular}

類に過ぎなかつた.これら各群集の出現頻度は表示のと おりAe. flavopictus 群集が最も高く全体の $73.7 \%$ で あり,Ae. Alavopictus, Ae. albopictus 群集は $15.8 \%$ で あり，Ae. albopictus 群集は最も低かつた，またそれぞ れの群集に属する幼虫数の割合もほぼ上記の出現頻度に 類似していた．小山のモウソウチク切株に出現した幼虫 群集は先に報告 ${ }^{3 !}$ したとおり 21 種類の多きにおよんだの であるが，今回のマダケ切株に出現した幼虫群集は僅か に 3 種類であつて，モウソウチク切株に扔ける蚊幼虫相 および幼虫群集の構成が極めて多種多様であつたのに反 して，マダケ切株におけるそれらが極度に賓弱であるこ とが理解される。

次にこれら各群集の出現瀕度および個体数の遷移を, それぞれ各採集回における総数に対する百分率を以て示 すと図 2 のおりである.まず各幼虫群集の出現頻度の 遷移についてみると, Ae. flavopictus 群集は 5 月中旬 から 10 月中旬まで常に最も優位を占めており，特にそ の頻度実数は，図示してはないが 8 月 30 日に最高に達 した. A e. albopictus 群集はこの期間中散発的に出現し たのであるが，6月 20 日にはその出現頻度はAe. fla vopictus 群集と相ならんでともに優位を占めた。なおこ の時期は図 1 に示したようにAe. Alavopictus の発生個 体数が最も少なく，また出現頻度が最も低い時であつ た. Ae. Alavopictus-Ae. albopictus 群集は 5 月中旬加 ら 6 月上旬までと 8 月から 9 月 12 日までにのみ出現し, 他の時期にはみられなかつたのであるが，そのうち 5 月 下旬にはその出現頻度はやや高、が，しかし Ae. $f a$ vopictus 群集のそれにはおよばなかつた。なお $A e$. flavopictus-Ae. alboptctus 群集の出現期は，図 1 から わかるようにこの群集を構成するそれぞれの蚊が最も多 く発生した時期と一致していた.

また各幼虫群集の個体数の遷移は大略上記した出現頻 度の遷移に伴つて変化しているが，しかし部分的には多 少異なる点もある，すなわち，Ae.\|fAavopictus 群集の 


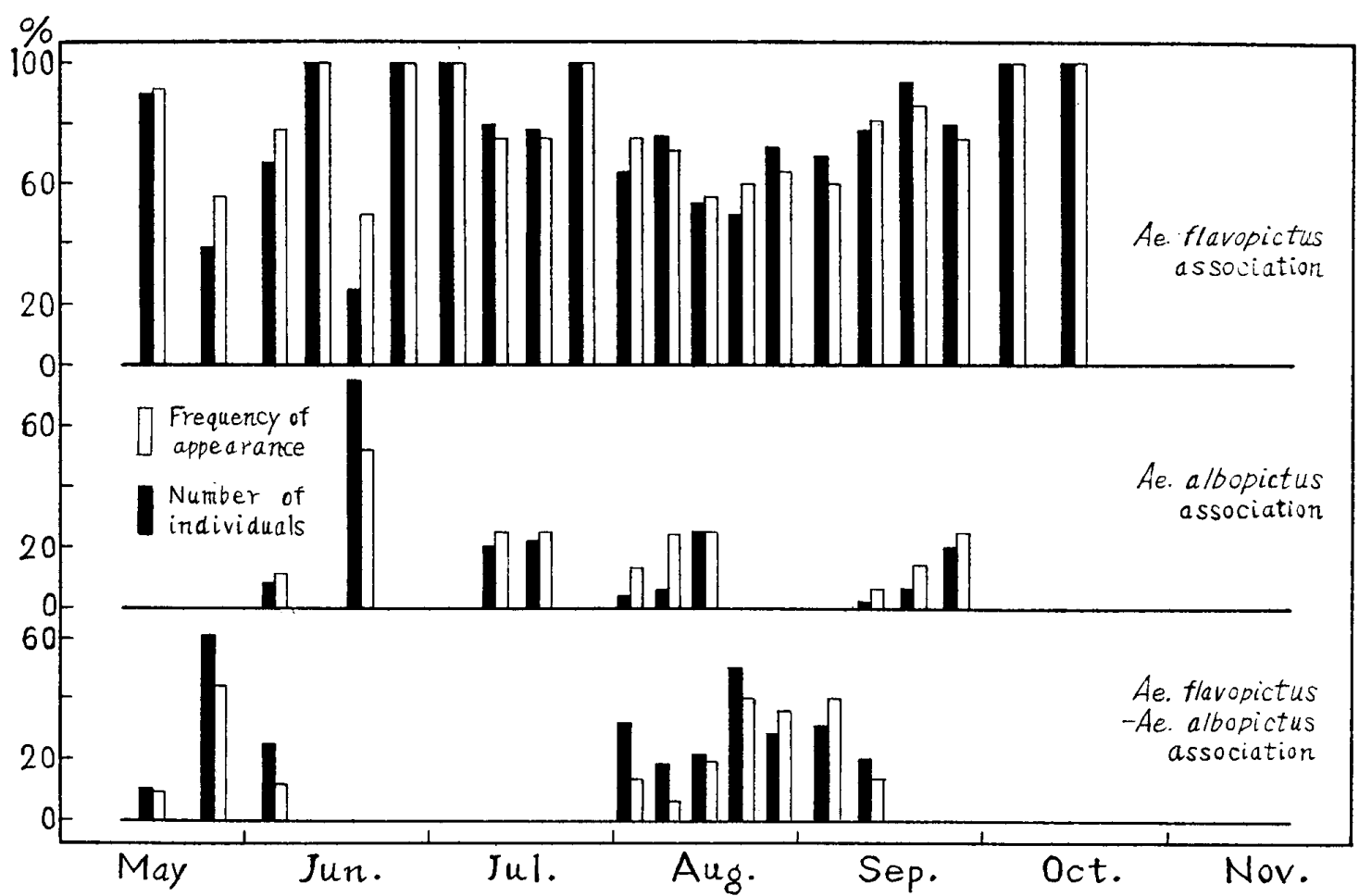

Fig. 2 Seasonal succession of larval associations of the mosquitoes in bamboo stumps (Length of the pillar indicates the percentage of each association to total number at each survey)

Table 4 Number of various mosquito larvae found in the same stump and number of stumps in which each species appeared, during the period from June to September

\begin{tabular}{|c|c|c|c|c|c|c|c|c|c|}
\hline \multirow{2}{*}{ Species } & \multirow{2}{*}{$\begin{array}{l}\text { Number } \\
\text { of speci- } \\
\text { es }\end{array}$} & \multirow{2}{*}{\multicolumn{2}{|c|}{ Number of stumps }} & \multicolumn{6}{|c|}{ Number of larvae } \\
\hline & & & & \multicolumn{2}{|c|}{ Ae. flavopictus } & \multicolumn{2}{|c|}{$\begin{array}{l}\text { Ae. } \\
\quad \text { albopictus }\end{array}$} & \multicolumn{2}{|c|}{ Total } \\
\hline $\begin{array}{l}\text { Ae. flavopictus } \\
\text { Ae. albopictus }\end{array}$ & 2 & 24 & $\begin{array}{l}(\%) \\
80.0\end{array}$ & 292 & $\begin{array}{l}(\%) \\
74.5\end{array}$ & 71 & $\begin{array}{l}(\%) \\
100.0\end{array}$ & 363 & $\begin{array}{l}(\%) \\
78.4\end{array}$ \\
\hline Ae. flavopictus & 1 & 6 & 20.0 & 100 & 25.5 & & & 100 & 21.6 \\
\hline Ae. albopictus & 1 & & & & & & & & \\
\hline Totol & & 30 & & 392 & & 71 & & 463 & \\
\hline
\end{tabular}

個体数は終始ほぼ優位を保ち，特にその個体実数は 8 月 30 日に最も多かつたが，しかし5月下旬には Ae. flavopictus-Ae. albopictus 群集が，また 6 月 20 日には, Ae. albopictus 群集が Ae. flavopictus 群集に代つて優 位となり,さらに8月 24 日には Ae. flavopictus-Ae. albopctus 群集は Ae. flavopictus 群集と相ならんでと もに優位を占めた.

\section{4. 個々の切株における较の発生状況}

マダケ切株 30 個につき調査したのであるが，そのう ち切株を固定して 継続調查を行なつた 6 月 20 日以降の 20 回の成績について述べる. これら 30 切株の個々につ いて, 調查期間中に同一切株に出現した蚊幼虫の種類や 個体数をまとめて示すと表 4 のとおりである.Ae. Ala. vopictus およびAe. albopictus の 2 種を発生した切株
が 24 株で全体の $80 \%$ を占め，Ae. flavopictus のみを 発生したものは 6 株で全体の $20.0 \%$ であり，また Ae. albopictus のみを発生した切株は皆無であつた．換言す れば，同一切株には同一時期であってもあるいは異なつ た時期であつても，上記両種の蚊が発生した場合が最も 多く,Ae. Alabopictusのみが発生した場合が少しあり, Ae. albopictus のみを発生した場合は 1 つむかつたの である. 上述のことから，マダケ切株には Ae. albopictus および Ae. albopictus が別個の切株に出現するよ りも同一の切株に発生する場合の方がはるかに多いこと がわかる．このことは先に報告した小山のモウソウチク 切株においても同様であつた. 1 株に発生した蚊の個体 数は個々の切株によつてかなりの差があつて 4 57 個体 であり，小山のモウソウチク切株における13〜122 個体 
记くらベるとずつと少ない，今回調査したマダケ切株の 内径は 1.7 4.7 cm であり，小山のモウソウチク切株 の内径 3.5 11.0 cm に比しはるかに小さいのであつ て，蚊幼虫の発生量が切株の内径ひいては水量等に関係 あることがうかがわれる。一般に切株の内径が大きく水 量の豊かなものの方が幼虫の発生量が多かつた。

5. Ae. Aavopictus と Ae. albopictus の“桡み わけ"について

中田ら (1953) ${ }^{57}$ 注京都の竹林モウソウチク切株におい てAe. flavopictus とAe. albopictus との間に“棲み :わけ”のあることを報告したが，著者(1960 a $)^{3 /}$ は小山 の竹林モウソウチク切株においてこれら両種の間に棲み わけの認められないことを報告した，今回の宇都宮の竹 林マダケ切株においては，既に表に関して述べたように Ae. Alavopictus および Ae. albopictus の両種はそれぞ れ単独群集として出現し，その出現頻度率は $73.7 \%$ お よび $10.5 \%$ を示したが，しかしこれら両種はまた混合 群集としても出現するのであつてその率は $15.8 \%$ を示 した.さらに表 4 に関して述べたように，この調査期間 をとおして同一切株に発生した蚊幼虫を調查した結果 は，これら両種の蚊が発生した切株は全切株数の $80 \%$ 核し，Ae. flavopictus のみを発生した切株は $20 \%$ で 河，Ae. albopictus のみを発生した切株は 1 個もなか つたのである。上述のように今回の調查においても，

Ae. flavopictus と Ae. albopictus との間には棲みわけ の現象が認められなかつた。

\section{要 約}

1） 1957 年 5 月から 11 月まで, 宇都宮市の 1 竹林マ 多ケ切株 30 個につき，24 回延 720 水域について蚊幼虫 の調査を行なつた。

2）採集された蚊は僅かに 1 属 2 種 537 個体で，その うち Aedes flavopictus が圧倒的に多く $85.3 \%$ 占め, Aedes albopictus は $14.7 \%$ であつた.

3) 蚊幼虫の季節的消掕については, Ae. flavopictus は常に優勢であり，本種は 8 月下旬に，また Ae. albopictus は8月中, 下旬に最も多数出現し, 前者は 10 月 下旬に，また後者は 10 月上旬に姿を消した。

4) 蚊幼虫群集については, 僅かに Ae. flavopictus 群集 $(73.7 \%)$, Ae. flavopictus-Ae. albopictus 群集 (15.8\%)およびAe. albopictus 群集(10.5\%)の 3 種が 出現したに過ぎなかつた。

5）マダケ切株においても，Ae. flavopictus とAe. .albopictus との間に“棲みわけ”の現象は認められな
かつた。

6）先に報告したモウソウチク切株における蚊幼虫相 に比較すると，今回のマダケ切株における幼虫相は極め て貧弱であり, 幼虫の種類も個体数もはなはだ少なかつ t.

\section{文献}

1) Kato, M. and Toriumi, M. (1951): Studies in the associative ecology of insects. IV. Synecologic al analysis of the Larval association of mosquitoes in the bamboo thicket. Sci. Rep. Tohoku Univ., 19 （2）：152-160. 一2）加藤陸奥雄 (1955)：蚊の生態, DDT 協会，東京，一3）弇茂好雄(1960a）：栃木 県の竹林に扣りる蚊の生態学的研究. 第 1 報, 小山 市の竹林に扣ける蚊幼虫. 宇都宮大学学芸学部研究 論集，No. 10，Sec. 2：29-39. -4) 倉茂好雄 (1960 b) : 栃木県の竹林に扣ける蚊の生態学的研究. 第2 報, 杤木県の竹林に扣りる蚊幼虫相之関西扣上び東 北地方の竹林に扣けるそれとの比較. 医学々生物学, 57 (6)：204-207．－5）中四五一・松尾喜久男・伊藤 寿美代 (1953)：京都市附近に扣ける蚊の生態学的研 究.（1）募地及び竹林内微阹水域に扣りる蚊幼虫相の 要移について。衛生動物， $4(3 \cdot 4): 62-71$. -6) 榊 原慎吾 (1956)：冬期に扣ける竹箠の蚊族幼虫群集. 三重大学学芸学部研究紀要, $15: 1-8$.

\section{Summary}

During the period from May to November, 1957, the writer investigated twenty-four times on thirty stumps of bamboo (Phyllostachys bambusoides Sieb. et Zucc.) in a bamboo grove in Utsunomiya City.

1. The mosquito larvae collected were of only two species: Aedes flavopictus (85.3\%) and Aedes albopictus (14.7\%).

2. Ae. flavopictus always appeared dominant and reached their maximum number at the end of August. Ae. albopictus reached their maximum number in the middle and end of August. The former disappeared at the end of October, while the latter at the biginning of the same month.

3. In the bamboo stumps there were formed only three kinds of larval associations: Ae. flavopictus association (73.7\%), Ae. flavopictus-Ae. albopictus association (15.8\%) and Ae. alvopictus association (10.5\%).

4. There was not seen the phenomenon of "habitat segregation" between Ae. flavopictus and Ae. albopictus in the bamboo stumps.

5. Compared with larval fauna of the mosquitoes in the stumps of another kind of bamboo (Mosochiku) formerly reported by the writer, in the present case the results were very poor, i. e. much smaller in number of species and individuals. 